\title{
Milk selenium concentration and its association with udder health in Atlantic Canadian dairy herds
}

\author{
A. Ceballos-Marquez, ${ }^{*} \dagger^{1}$ H. W. Barkema, $₫ \S$ H. Stryhn, ${ }^{*}$ I. R. Dohoo, ${ }^{*}$ G. P. Keefe, ${ }^{*}$ and J. J. Wichtel ${ }^{*}$ \\ ${ }^{*}$ Centre for Veterinary Epidemiological Research, Department of Health Management, Atlantic Veterinary College, University of Prince \\ Edward Island, Charlottetown, PEI C1A 4P3, Canada \\ †Departamento de Sistemas de Produccion, Universidad de Caldas, Manizales, Colombia \\ $\ddagger$ Department of Production Animal Health, Faculty of Veterinary Medicine, University of Calgary, Calgary, AB T2N 4N1, Canada \\ $\S$ Department of Reproduction, Obstetrics and Herd Health, Faculty of Veterinary Medicine, Ghent University, Merelbeke, Belgium
}

\begin{abstract}
Soils and plants in Atlantic Canadian provinces are known to contain low concentrations of selenium (Se). Earlier studies have indicated that dairy producers in Atlantic Canada are providing insufficient supplementary Se in the ration to meet the Se requirements of dairy cattle, as measured by herd-level milk Se concentration. The objective of this study was to evaluate the association between milk Se concentration and somatic cell count (SCC) and the risk of new intramammary infection (IMI) in the dry period, in Atlantic Canadian dairy cows. Eighteen dairy farms participating in the Canadian Bovine Mastitis Research Network cohort study were selected as a convenience sample. On each farm 15 cows to be dried off were selected. Quarter milk samples were collected at 4 and 2 wk before dryingoff, within $24 \mathrm{~h}$ after calving, and at $7 \mathrm{~d}$ after calving to evaluate IMI status. Composite milk samples were analyzed for SCC and Se concentration. Mean milk Se concentration was marginal in $14 \%$ of the cows that were on pasture during the grazing season. Milk Se concentration was not associated with the overall odds of new IMI in the dry period; however, the odds of having a new Streptococcus spp. and other gram-positive pathogen IMI in the dry period increased with increasing milk Se concentration. Somatic cell count increased with milk Se concentration, even after adjusting for IMI status. The dairy population in our study had higher ranges for milk Se concentration, whereas ranges for prevalence of IMI, and SCC were lower, compared with those in studies where a negative relationship between Se status and udder health was first noted. Therefore, under the current management conditions, milk Se concentration did not appear to be a principal determinant of udder health.
\end{abstract}

Received April 3, 2010.

Accepted May 26, 2010.

${ }^{1}$ Corresponding author: alejandro.ceballos@ucaldas.edu.co
Key words: selenium, udder health, intramammary infection, somatic cell count

\section{INTRODUCTION}

Much research and effort have been dedicated to mastitis and its control strategies in dairy herds. Nevertheless, mastitis remains as a major challenge to the worldwide dairy industry because it restricts farm profitability both directly and indirectly. Economic losses are due to decreased milk yield, costs of drugs, early culling, extra labor, discarded milk, and increased rate of cow replacement (Halasa et al., 2007). A nationwide study conducted in 106 Canadian dairy herds reported an overall mean and median incidence rate of clinical mastitis (CM) of 23 and 17 cases per 100 cow-years, respectively, with Staphylococcus aureus, Escherichia coli, Streptococcus uberis, and CNS being the most frequently isolated pathogens (Olde Riekerink et al., 2008). In Prince Edward Island (PEI), at least $74 \%$ of dairy herds have at least one cow with a Staph. aureus IMI (Olde Riekerink et al., 2006).

Suboptimal nutrition is a recognized management risk factor for infectious disease in cattle (e.g., mastitis); in particular, Se and vitamin $\mathrm{E}$ have been extensively studied in the context of their role in udder health (Smith et al., 1997). North American and European studies in dairy herds with good control of CM caused by major pathogens found a negative association between Se status and bulk tank SCC (BTSCC; Erskine et al., 1987; Weiss et al., 1990; Ndiweni et al., 1991). A Canadian study found, however, that bulk tank milk Se concentration (BTSe) was not associated with herdlevel udder health parameters (Wichtel et al., 2004).

Soils in many regions of the world, including Atlantic Canada, have low Se content; consequently, cattle fed forages and crops grown on soils containing less than $0.6 \mathrm{mg}$ of $\mathrm{Se} / \mathrm{kg}$ may receive suboptimal dietary Se (Winter and Gupta, 1979). Therefore, locally grown feeds in Atlantic provinces do not provide enough Se to meet the requirements of cattle according to the current 
recommendation in diets for dairy cows (NRC, 2001). Canadian surveys have indicated that Se deficiency is a nationwide problem (Fenimore et al., 1983; Campbell et al., 1995), finding the lowest Se status in cattle raised in eastern Canada. Recent studies evaluating Se status by BTSe have found that lactating cows in $59 \%$ of PEI dairy herds were either marginally or truly Sedeficient, as many producers are providing insufficient supplementary Se for lactating dairy cows (Wichtel et al., 2004).

Little is known about the status of Se and its association with udder health in Canadian dairy herds. In the study of Wichtel et al. (2004), milk Se was measured during lactation, but not at dry-off or at calving, 2 critical periods for udder health and 2 periods in lactation cycle when supplementation may be inconsistent because of the transition in dietary management or reduced feed intake. Because no studies have been conducted in Atlantic Canada concerning the association of Se status (as measured by individual cow milk Se concentration) with mammary gland health, and because evidence indicates that the daily intake of Se in lactating dairy cows from this region tends to be lower than the current NRC recommendation, we hypothesized that an adequate Se status (i.e. high cow-level milk Se concentration) may be associated with an improvement of measures of udder health (e.g., lower risk of having a new IMI in the dry period, and lower SCC around calving) in dairy cows from selected dairy herds in Atlantic Canada. The objective of this study was to evaluate the association of individual milk Se concentration with SCC and the risk of having a new IMI in the dry period in Atlantic Canadian dairy cows.

\section{MATERIALS AND METHODS}

This study was approved by the Animal Care Committee of the University of PEI in accordance with the requirements of the Canadian Council on Animal Care.

\section{Herd and Animal Selection}

In total, 18 dairy farms from New Brunswick ( $\mathrm{n}=$ $5)$, Nova Scotia $(\mathrm{n}=5)$ and PEI $(\mathrm{n}=8)$ participating in the Canadian Bovine Mastitis Research Network (CBMRN) cohort study were selected as a stratified convenience sample (Reyher et al., 2010). The selection process was based on strata of low, intermediate, and high 12-mo rolling average BTSCC in 2006, reflecting BTSCC averages of $<150,000$, from 150,000 to 300,000 , and $>300,000$ cells $/ \mathrm{mL}$, respectively. Eleven farms used a free-stall barn system for housing lactating cows, with cows confined over the year in 6 of those herds. Cows were housed over the year in 1 tie-stall barn herd, while cows accessed to pasture in the remaining tie-stall herds $(\mathrm{n}=6)$. On average, cows grazed 6 mo of the year, ranging from 3 to 8 mo. All herds had $>80 \%$ Holstein-Friesian cows, were milked twice daily, and were DHI members. The relative proportion of tie-stall versus free-stall herds in the study was reflective of the target population for each province. Dairy production systems were classified as follows: intensively managed herds with cows housed in tie-stall or free-stall barns over the year, and intensively managed herds with cows on pasture in the grazing season (i.e., spring and summer). The study was conducted from February 2007 to January 2008 (Reyher et al., 2010).

Cows were selected to participate in the study if they were to be dried off over the 2 mo following the farm visit, and if the cow was expected to remain in the herd at least 2 wk after calving. On average, 14 cows (between 8 and 19 cows per herd) met the selection criteria. The length of the dry period was, on average, 63 d (95\% CI: 60, 66). Cows calved between April and December 2007.

\section{Sampling and Data Collection}

Farm personnel aseptically collected quarter milk samples of selected cows between 4 and 2 wk before drying-off, and a second set of samples was collected from 2 wk before drying-off to drying-off. Quarter milk samples from cows were collected from calving to $24 \mathrm{~h}$ after calving, and resampled $7 \mathrm{~d}$ after the first sample after calving. Additionally, the farmer was asked to aseptically collect milk samples from those quarters that had physical signs of CM (any visual abnormality of udder or milk, with or without systemic signs of disease) at the time the abnormality was noted. Immediately after collection, samples were frozen on farm, and sent to the Atlantic Veterinary College (Charlottetown, PEI, Canada).

Two composite milk samples were created for SCC and milk Se analyses. For the pre-dry sample, an aliquot of each quarter milk sample collected 2 wk before drying-off was mixed; for the post-fresh sample, an aliquot of each quarter sample collected $7 \mathrm{~d}$ after calving was mixed. During the monthly visits of CBMRN technicians to the farms, a bulk tank milk sample for Se analysis was collected in 17 of 18 study dairy herds in April, July, and October 2007, and January 2008, to represent spring, summer, fall, and winter periods.

A questionnaire with closed and semiclosed questions was administered at each farm at the end of the study period to gather information on Se supplementation practices. Specific herd data such as BMSCC and herd size and specific cow data such as parity, milk yield, 
and calving date were obtained from the regional DHI organization.

\section{Laboratory Analysis}

Bacteriological analyses of milk samples were performed according to protocols established by the CBMRN (Reyher et al., 2010). An aliquot of $0.01 \mathrm{~mL}$ was cultured from all quarter milk samples, counting colonies when $\leq 10 /$ plate (equivalent to $\leq 1,000 \mathrm{cfu} / \mathrm{mL}$ ). Pathogen identification was as follows: Staph. aureus was identified by Gram stain and double-zone hemolysis on blood agar. Coagulase-negative staphylococci were identified by Gram stain and no hemolysis on blood agar; however, if colonies were $\geq 10$ /plate, coagulase and deoxyribonuclease degradation tests were set up for identification. Staphylococcus aureus was confirmed by a positive reaction to deoxyribonuclease degradation test, whereas CNS were confirmed when negative for both tests. Streptococci were identified by Gram stain and negative catalase test. Christie, Atkins, Munch-Petersen (CAMP), esculin, hippurate, inulin, and raffinose tests were set up for identification. When necessary, the API 20 Strep System (bioMérieux SA, Marcy l'Etoile, France) was used to identify Strep. uberis. Streptococcus dysgalactiae was confirmed by a positive latex agglutination test. Gram-positive, and catalase positive rods were considered to be Corynebacterium spp. or Bacillus spp. Escherichia coli and Klebsiella spp. were identified by Gram staining, being oxidase negative, and their typical appearance on MacConkey agar. Identification of genera was made after setting up urea, citrate, spot indole, and triple-sugar iron tests. Other gram-negative rods or cocci, and positive oxidase test were considered to be other gram-negative bacteria.

Composite milk samples were refrigerated or refrozen in preparation for SCC and Se analyses. Milk SCC was determined using a Foss 4000 cell counter (Foss Electric, Hillerød, Denmark). Milk Se concentration was evaluated by the graphite furnace atomic absorption spectroscopy method, which has sensitivity of $0.13 \mu \mathrm{mol}$ Se/L, an accuracy of $98 \%$, and a precision $>95 \%$ (Oster and Prellwitz, 1982). Readings were carried out using a spectrometer PerkinElmer AAnalyst 800 (PerkinElmer, Waltham, MA).

The milk Se concentration was expressed as micromoles per liter. Reference ranges for BTSe were as follows: $<0.12 \mu \mathrm{mol} / \mathrm{L}$ is considered to represent deficiency, whereas $0.20 \mu \mathrm{mol} / \mathrm{L}$ divided the marginal range into high- and low-marginal categories, and $0.28 \mu \mathrm{mol} / \mathrm{L}$ or higher was taken to represent adequacy (Wichtel et al., 2004). Wichtel et al. (2004) established the reference range for BTSe by a regression model of the mean herd serum Se concentration on the BTSe concentration of
15 PEI dairy herds with widely differing BTSe concentrations. The cut-off points for BTSe were selected by calculating the point at which the published reference values for serum Se intersected the regression line of the model.

\section{Definition of IMI}

A sample was considered culture-positive when $\geq 1 \mathrm{cfu} / 0.01 \mathrm{~mL}$ (equivalent to $\geq 100 \mathrm{cfu} / \mathrm{mL}$ ) of any pathogen was isolated. A quarter was considered to have an IMI at drying-off when both samples collected at drying-off were culture-positive for the pathogen in question. A quarter with an IMI at drying-off that was negative for both samples collected after calving was considered as cured over the dry period. An IMI was established in the dry period when a quarter sample was culture-positive for a pathogen in at least one of the samples collected after calving. An IMI established in the dry period was considered as new if both quarter samples collected at drying-off were culture-negative for the pathogen in question.

The number of recovered (i.e., cured) quarters was recorded. Samples containing more than 2 bacterial species were considered contaminated and were not informative of IMI status. However, if Staph. aureus or Streptococcus agalactiae were found in a contaminated plate, the sample was considered culture-positive for the isolated pathogen.

\section{Statistical Analysis}

Separate analyses were carried out for milk Se concentration, occurrence of new IMI, and SCC. The following general steps were part of all analyses. Unconditional associations between independent and dependent variables were established in models incorporating the relevant hierarchical data structure (as detailed below). All independent variables unconditionally associated $(P \leq 0.10)$ with the dependent variables were included in a multivariable model, which was manually reduced by backward selection of the significant variables $(P \leq$ 0.05). All analyses included the following independent variables: province (PEI, New Brunswick, and Nova Scotia), season [winter (December 21 to March 20), spring, summer, and fall], housing system (free-stall or tie-stall barn), whether or not cows were on pasture in the grazing season, and parity $(1,2$ to $3,>3)$. First-order interactions of significant variables were also assessed. Significant associations were assessed by pairwise comparisons with a Bonferroni adjustment for multiple testing.

Milk Selenium. The dependent variable "milk Se concentration obtained from each of the 2 composite 
samples per cow (before drying-off and postcalving)" was analyzed by linear mixed models with the previously listed independent variables. Clustering within herds and cows was accounted for by including herd random effects and a compound symmetry correlation structure within cows (Dohoo et al., 2009). The model assumptions were evaluated by examining the standardized residuals, and significant associations were represented by model-based least squares means. Linear mixed model analysis was carried out using the MIXED procedure of SAS (version 9.2, SAS Institute Inc., Cary, NC).

Incidence Risk of IMI. The dependent variable "occurrence of a new IMI with a specific pathogen (or overall) after calving in a quarter not infected at dryingoff" was analyzed by logistic models with the previously listed independent variables plus the cow-level milk Se concentration at drying-off. Clustering within cows and herd was accounted for by the alternating logistic regression algorithm (Kleinbaum and Klein, 2002; Dohoo et al., 2009). Significant associations were represented by odds ratios with a population-averaged interpretation across all cows and herds. Alternating logistic regression analysis was carried out using the GENMOD procedure of SAS (version 9.2, SAS Institute Inc.).

$\boldsymbol{S C C}$. The dependent variable "SCC obtained from each of the 2 composite samples per cow (before dryingoff and postcalving)" was analyzed (on natural log scale) by linear mixed models similar to those described previously for milk Se concentration, except that this latter variable was included as an independent variable. The effect of the cow-level IMI status at drying-off, defined by parallel interpretation of the corresponding quarterlevel IMI status, was evaluated by fitting additional models with this independent variable included. Cowlevel IMI status should be considered as an intermediate (intervening) variable for the association between milk Se and SCC; the 2 analyses therefore gave the total and direct effects of milk Se, respectively (Dohoo et al., 2009). An optimal power transformation of SCC was obtained by Box-Cox analysis (Dohoo et al., 2009) because the model assumptions for the analysis on log scale were not fully met; however, a log-transformation of SCC ( $\mathbf{L n S C C}$ ) was used in the final model (Ali and Shook, 1980).

\section{RESULTS}

Two PEI herds left the study before the completion of the after calving follow-up period; thus, the information on quarter samples collected after calving from 23 cows was not available for analysis. Additionally, 14 cows did not calve during the study period, and quarter samples from 7 cows were not collected after calving.
The herd average number of lactating cows over the study period was 81, ranging between 42 and 197, with an average parity of 3 , with values ranging from 1 to 9 . The average daily milk yield was $31.6 \pm 3.5 \mathrm{~kg} / \mathrm{cow}$, ranging from 20 to $47 \mathrm{~kg} / \mathrm{d}$.

The 12-mo rolling average BTSCC ranged from 95,000 to 328,000 cells $/ \mathrm{mL}$, with a geometric mean of 173,000 cells/mL across all herds over the study period. Rolling average for 2 dairy herds was $<150,000$, between 150,000 and 300,000 for 13 herds, and $>300,000$ cells/mL for 3 herds.

\section{Milk Selenium}

All farmers reported the inclusion of Se in the ration for bred heifers, dry and lactating cows all year round. Adding Se to concentrates was the preferred method for supplementation. Three producers reported an additional supplementation using a free-choice mineral block, a top dress for pasture, and an injectable preparation at drying-off on one herd each. Mean and standard deviation of BTSe were $0.52 \pm 0.12 \mu \mathrm{mol} / \mathrm{L}$; only 2 samples from 2 different herds had a BTSe $<0.28$ $\mu \mathrm{mol} / \mathrm{L}$.

A total of 427 composite milk samples from 262 cows in 18 dairy herds were included in the final analysis. Mean individual milk Se concentration was $0.52 \pm 0.17$ $\mu \mathrm{mol} / \mathrm{L}$, with 8 cows $(3 \%)$ having a milk Se concentration $<0.28 \mu \mathrm{mol} / \mathrm{L}$. No differences were observed in milk Se concentration due to province, parity, or stage of lactation, whereas the unconditional analysis indicated seasonal variation and differences due to the housing system, and whether or not cows were allowed to graze (Table 1). Neither housing system nor the interactions between season and grazing and housing system and grazing were associated with milk Se concentration, and were removed from the final model (Table 2). There was a significant seasonal variation of milk Se concentration, and the highest milk Se concentration was found in cows confined all year round (Table 2).

A high correlation $(\rho=0.43)$ was found for milk Se concentrations between cows within the same herd.

\section{IMI}

The association of milk Se concentration with the odds of new IMI in the dry period were evaluated using 3,816 quarter milk samples from 262 cows in 18 Atlantic Canadian herds. At drying-off, 2,080 quarter milk samples were collected and cultured; of these, $17 \%$ were contaminated (Table 3) and omitted from further analysis. Only 1,736 quarter milk samples were collected after calving because of cows lost to followup; the proportion of contaminated samples was $12 \%$ (Table 3). 
Table 1. Unconditional associations obtained from a linear mixed model for milk selenium concentration $(\mu \mathrm{mol} / \mathrm{L})$ in 427 composite samples from 262 cows in 18 Atlantic Canadian dairy herds

\begin{tabular}{|c|c|c|c|}
\hline Variable & $\mathrm{LSM}^{1}$ & $95 \% \mathrm{CI}$ & $P$-value \\
\hline Province & & & 0.24 \\
\hline Prince Edward Island & 0.49 & $0.40,0.58$ & \\
\hline New Brunswick & 0.49 & $0.37,0.60$ & \\
\hline Nova Scotia & 0.60 & $0.49,0.71$ & \\
\hline Season & & & $<0.01$ \\
\hline Fall & 0.53 & $0.46,0.61$ & \\
\hline Winter & 0.58 & $0.49,0.66$ & \\
\hline Spring & 0.55 & $0.49,0.62$ & \\
\hline Summer & 0.47 & $0.41,0.53$ & \\
\hline Housing system & & & 0.02 \\
\hline Free-stall barn & 0.57 & $0.50,0.64$ & \\
\hline Tie-stall barn & 0.44 & $0.36,0.53$ & \\
\hline Grazing & & & $<0.01$ \\
\hline No & 0.58 & $0.52,0.64$ & \\
\hline Yes & 0.47 & $0.41,0.53$ & \\
\hline Parity & & & 0.16 \\
\hline 1 & 0.53 & $0.46,0.59$ & \\
\hline 2 to 3 & 0.53 & $0.47,0.59$ & \\
\hline$>3$ & 0.50 & $0.44,0.57$ & \\
\hline Stage of lactation & & & 0.59 \\
\hline Fresh & 0.52 & $0.45,0.58$ & \\
\hline Drying-off & 0.53 & $0.46,0.59$ & \\
\hline
\end{tabular}

${ }^{1}$ Least squares means.

At drying-off, $40 \%$ of the quarter milk samples were culture-positive. Coagulase-negative staphylococci were the most frequently isolated group of bacteria, followed by other gram-positive bacteria and Streptococcus spp. (Table 3). After calving, 35\% of the quarter milk samples were culture-positive, with CNS, other grampositive bacteria, Staph. aureus, and Streptococcus spp. being the most common isolations (Table 3). No milk sample was Streptococcus agalactiae-positive.

The prevalence of IMI at drying-off was $22 \%$ (i.e., both pre-dry samples positive), with CNS being the most frequently isolated bacteria (70\%), followed by Staph. aureus (12\%), other gram-positive pathogens $(9 \%)$, and Streptococcus spp. (4\%). The proportion of IMI that cured over the dry period was $39 \%$, ranging from 21 to $100 \%$ depending upon the pathogen (Table 4). The incidence of new IMI in the dry period was $59 \%$; of these CNS IMI were $41 \%$, followed by other gram-positive pathogens IMI (21\%), Streptococcus spp. IMI (13\%), and Staph. aureus IMI (9\%) (Table 4).

The unconditional association of milk Se concentration with the odds of new Staph. aureus IMI and CNS IMI was not significant (Table 5). However, the odds of new Streptococcus spp. IMI unconditionally increased with increasing milk Se concentration. An increase of $0.20 \mu \mathrm{mol} / \mathrm{L}$ in milk Se concentration was associated with 1.88 times higher odds of having a new Streptococcus spp. IMI (Table 5). Adjusting the association of milk Se concentration with the odds of new pathogenspecific IMI for the effect of other variables produced only minor changes in the coefficients (Table 6).

\section{SCC}

The association of individual milk Se concentration with SCC was based on 313 composite milk samples, because contaminated samples were removed from the analysis. Geometric mean SCC was 56,000 cells $/ \mathrm{mL}$, with samples ranging from 3,000 to $8,240,000$ cells/ $\mathrm{mL}$. The unconditional associations of LnSCC with all independent variables are presented in Table 7.

The model validation showed a right-skewness in the residuals that could be eliminated using power transformation (optimal power of -0.25 obtained by Box-Cox analysis). However, the conclusions of the effect of milk Se concentration on SCC either after power transformation (not shown) or after log-transformation were qualitatively similar. Therefore, results are presented using the log-transformation for simplicity of interpretation.

Two multivariable models, either including or not including cow-level IMI status as an independent variable, were fitted (Table 8). Both models indicated a positive association of milk Se concentration with mean LnSCC; the analysis of power-transformed SCC confirmed this finding (not shown). However, the coefficient for milk Se concentration increased slightly $(\sim 10 \%)$ and was still positive after controlling for infection status (Table 8), indicating a direct association of milk Se with LnSCC.

The multivariable linear regression model indicated a lower mean LnSCC in the spring compared with the summer $(P<0.01)$. Primiparous cows had lower LnSCC than multiparous cows $(P<0.01)$, and there were no significant differences associated with parity $(P=0.24)$. Mean LnSCC was higher at drying-off than in fresh cows (Table 8). The IMI status also affected LnSCC: a lower LnSCC was found in negative IMI cows compared with cows having an IMI $(P<0.01)$. Cows with major pathogen IMI had higher LnSCC than cows with CNS IMI $(P<0.01)$. Although there was a signifi-

Table 2. Multivariable linear mixed model estimates of the associations of season and grazing with milk selenium concentration $(\mu \mathrm{mol} / \mathrm{L})$ in 427 composite samples from 262 cows in 18 Atlantic Canadian dairy herds

\begin{tabular}{llll}
\hline Variable & Mean $^{1}$ & $95 \% \mathrm{CI}$ & $P$-value \\
\hline Season & & & $<0.001$ \\
Fall & $0.51^{\mathrm{a}}$ & $0.44,0.59$ & \\
Winter & $0.60^{\mathrm{ab}}$ & $0.52,0.69$ & \\
Spring & $0.65^{\mathrm{b}}$ & $0.58,0.73$ & \\
Summer & $0.58^{\mathrm{a}}$ & $0.50,0.66$ & $<0.001$ \\
Grazing & & & \\
No & $0.62^{\mathrm{a}}$ & $0.54,0.69$ & \\
Yes & $0.45^{\mathrm{b}}$ & $0.38,0.51$ & \\
\hline
\end{tabular}

${ }^{\mathrm{a}, \mathrm{b}}$ Within a row, different superscripts differ significantly (adjusted $P$ $<0.05)$.

${ }^{1}$ Adjusted (least squares) means not including grazing for season effect, and only including spring and summer seasons for grazing effect. 
Table 3. Quarter sample distribution of mastitis pathogens at drying-off and after calving in 3,816 quarters from 262 cows in 18 dairy herds from Atlantic Canada

\begin{tabular}{|c|c|c|c|c|}
\hline \multirow[b]{2}{*}{ Sample status } & \multicolumn{2}{|c|}{ Drying-off } & \multicolumn{2}{|c|}{ After calving } \\
\hline & $\mathrm{n}$ & $\%$ & $\mathrm{n}$ & $\%$ \\
\hline Culture-negative & 887 & 42.6 & 919 & 52.9 \\
\hline Culture-positive & 832 & 40.0 & 611 & 35.2 \\
\hline Staphylococcus aureus & 50 & 2.4 & 59 & 3.4 \\
\hline Staphylococcus hyicus & 1 & 0.0 & 3 & 0.2 \\
\hline CNS & 490 & 23.6 & 299 & 17.2 \\
\hline Streptococcus spp. ${ }^{1}$ & 71 & 3.4 & 50 & 2.9 \\
\hline Streptococcus dysgalactiae & 3 & 0.1 & 7 & 0.4 \\
\hline Streptococcus uberis & 14 & 0.7 & 6 & 0.3 \\
\hline Escherichia coli & 2 & 0.1 & 7 & 0.4 \\
\hline Enterobacter spp. & & & 13 & 0.7 \\
\hline Corynebacterium spp. & 47 & 2.3 & 20 & 1.2 \\
\hline Klebsiella spp. & & & 3 & 0.2 \\
\hline Nocardia spp. & 1 & 0.0 & 6 & 0.3 \\
\hline Other gram-positive pathogens ${ }^{2}$ & 145 & 7.0 & 124 & 7.1 \\
\hline Other gram-negative pathogens ${ }^{3}$ & 1 & 0.0 & 7 & 0.4 \\
\hline Yeast & 5 & 0.2 & 2 & 0.1 \\
\hline Fungi & 2 & 0.1 & 5 & 0.3 \\
\hline Contaminated & 361 & 17.4 & 206 & 11.9 \\
\hline Total & 2,080 & & 1,736 & \\
\hline
\end{tabular}

${ }^{1}$ Strep. agalactiae, Strep. uberis, Strep. dysgalactiae, and Strep. canis were excluded from this category.

${ }^{2}$ Bacillus spp.

${ }^{3}$ Serratia spp., Citrobacter spp., Proteus spp., Salmonella spp., Pseudomonas spp., and Pasteurella multocida.

cant effect of season, parity, and stage of lactation on LnSCC, their interactions with milk Se concentration were not significant, with $P$-values of $0.84,0.87$, and 0.65 , respectively.

\section{DISCUSSION}

Bulk tank milk Se is an adequate indicator to monitor Se status in lactating cows, with BTSe $\geq 0.28 \mu \mathrm{mol} / \mathrm{L}$ reflecting adequacy (Wichtel et al., 2004). Using this cut-off, 2 PEI herds in which cows had access to pasture had marginal BTSe values in the summer, suggesting that Se intake was insufficient to meet the Se requirement in the grazing season.

Mean milk Se concentration of $0.35 \mu \mathrm{mol} / \mathrm{L}$ in cows fed Se-adequate diets has been found in Canadian studies (Fisher et al., 1980). In our study, $27 \%$ of the cows

Table 4. Intramammary infections at drying-off $(\mathrm{n}=730$ quarters), cured IMI over the dry period, and new IMI in the dry period $(\mathrm{n}=440$ quarters $)^{1}$

\begin{tabular}{|c|c|c|c|c|c|c|}
\hline \multirow[b]{2}{*}{ Pathogen } & \multicolumn{2}{|c|}{ IMI at drying-off } & \multicolumn{2}{|c|}{ Cured $^{2}$} & \multicolumn{2}{|c|}{ New IMI in dry period } \\
\hline & $\mathrm{n}$ & $\%$ & $\mathrm{n}$ & $\%$ & $\mathrm{n}$ & $\%$ \\
\hline Staphylococcus aureus & 19 & 2.6 & 4 & 21 & 23 & 5.2 \\
\hline CNS & 112 & 15.3 & 43 & 38 & 106 & 24.1 \\
\hline Streptococcus spp. ${ }^{3}$ & 6 & 0.8 & 3 & 50 & 33 & 7.5 \\
\hline Streptococcus dysgalactiae & 1 & 0.1 & 1 & 100 & 4 & 0.9 \\
\hline Streptococcus uberis & 4 & 0.5 & 1 & 25 & 4 & 0.9 \\
\hline Escherichia coli & - & - & - & - & 5 & 1.1 \\
\hline Enterobacter spp. & - & - & - & - & 2 & 0.5 \\
\hline Corynebacterium spp. & 4 & 0.5 & 4 & 100 & 9 & 2.0 \\
\hline Klebsiella spp. & - & - & - & - & 3 & 0.7 \\
\hline Nocardia spp. & - & - & - & - & 4 & 0.9 \\
\hline Other gram-positive pathogens ${ }^{4}$ & 14 & 1.9 & 6 & 43 & 55 & 12.5 \\
\hline Other gram-negative pathogens ${ }^{5}$ & - & - & - & - & 4 & 0.9 \\
\hline Yeast & - & - & - & - & 2 & 0.5 \\
\hline Fungi & 1 & 0.1 & 1 & 100 & 5 & 1.1 \\
\hline Total & 161 & 22.1 & 63 & 39 & 259 & 58.9 \\
\hline
\end{tabular}

${ }^{1}$ Contaminated samples were omitted from the analysis

${ }^{2}$ Cured IMI over the dry period.

${ }^{3}$ Strep. agalactiae, Strep. uberis, Strep. dysgalactiae, and Strep. canis were excluded from this category.

${ }^{4}$ Bacillus spp.

${ }^{5}$ Serratia spp., Citrobacter spp., Proteus spp., Salmonella spp., Pseudomonas spp., and Pasteurella multocida. 
Table 5. Unconditional effect of increasing milk selenium concentration by $0.2 \mu \mathrm{mol} / \mathrm{L}$, province, housing system, grazing, and parity on the odds of having pathogen-specific new IMI in the dry period in 440 quarters from 192 dairy cows from 16 Atlantic Canadian dairy herds

\begin{tabular}{|c|c|c|c|c|c|c|c|c|c|}
\hline \multirow[b]{2}{*}{ Variable } & \multicolumn{3}{|c|}{ Staphylococcus aureus } & \multicolumn{3}{|c|}{ Streptococcus spp. ${ }^{1}$} & \multicolumn{3}{|c|}{ CNS } \\
\hline & $\mathrm{OR}^{2}$ & $95 \% \mathrm{CI}$ & $P$-value & $\mathrm{OR}^{2}$ & $95 \% \mathrm{CI}$ & $P$-value & $\mathrm{OR}^{2}$ & $95 \% \mathrm{CI}$ & $P$-value \\
\hline Province & & & 0.10 & & & 0.01 & & & 0.02 \\
\hline Prince Edward Island & 1 & & & 1 & & & 1 & & \\
\hline New Brunswick & 0.30 & $0.05,1.67$ & & 2.12 & $0.87,5.20$ & & 0.61 & $0.42,0.87$ & \\
\hline Nova Scotia & 1.50 & $0.28,8.00$ & & 3.19 & $1.42,7.19$ & & 0.82 & $0.41,1.64$ & \\
\hline Tie-stall & 2.06 & $0.44,9.57$ & & 0.55 & $0.30,1.02$ & & 0.95 & $0.58,1.57$ & \\
\hline Grazing & & & 0.79 & & & 0.01 & & & 0.39 \\
\hline No & 1 & & & 1 & & & 1 & & \\
\hline Yes & 1.28 & $0.21,7.66$ & & 0.45 & $0.25,0.82$ & & 0.78 & $0.43,1.39$ & \\
\hline Parity & & & $<0.01$ & & & 0.99 & & & 0.30 \\
\hline 2 to 3 & 1 & & & 1 & & & 1 & & \\
\hline$>3$ & 2.92 & $1.64,5.23$ & & 1.00 & $0.48,2.06$ & & 1.26 & $0.81,1.96$ & \\
\hline
\end{tabular}

${ }^{1}$ Strep. agalactiae, Strep. uberis, Strep. dysgalactiae, and Strep. canis were excluded from this category.

${ }^{2}$ Odds ratio.

had milk Se levels $<0.35 \mu \mathrm{mol} / \mathrm{L}$ in the summer, and of these $64 \%$ were cows housed in tie-stall barns with access to pasture in the grazing season. Seasonal effects may be explained by a dilution effect. Even though this effect seems plausible, it is unlikely, because milk yield in the spring was $5 \%$ less than that in the fall, whereas the difference in milk Se concentration between those seasons was $28 \%$. Consequently, seasonal changes in milk Se concentration are more likely associated with a suboptimal intake due to low content; seasonal changes of Se content in Atlantic pastures, forages, and grains (Winter and Gupta, 1979); and differences in the amount of concentrate fed to dairy cows.

Approximately $90 \%$ of the cows had an adequate Se status as indicated by their milk Se concentration, most likely associated with the widespread recent adoption of improved Se supplementation practices in Atlantic herds. Although milk Se concentration changes rapidly in response to Se intake, not all methods for Se supplementation are equally efficacious (Wichtel, 1998; Wichtel et al., 2004; Ceballos et al., 2009), with dose and source of Se closely related to the response in milk Se concentration. On average, North American cows fed organic Se have $0.37 \mu \mathrm{mol} / \mathrm{L}$ more milk Se than cows supplemented with inorganic forms (Ceballos et al., 2009). Milk Se concentration increases as organic Se intake increases, and organic Se is better transferred to milk than inorganic sources (Ceballos et al., 2009). Therefore, an enhanced milk Se concentration in Atlantic Canadian herds as compared with former studies (Fisher et al., 1980; Wichtel et al., 2004) may be a consequence of increasing organic Se supplementation.

In all recent studies on prevalence of IMI and incidence of CM, CNS have been the most frequently isolated pathogens, whereas Staph. aureus is the major pathogen most frequently found (Olde Riekerink et al., 2008; Sampimon et al., 2009). It was, therefore, not surprising that CNS and Staph. aureus were often isolated in our study. Other major pathogens (e.g., Streptococcus spp. and other gram-positive pathogens) were also frequently isolated.

The results of our study concur with former studies indicating no relationship of Se status with the overall incidence of IMI and CM (Kommisrud et al., 2005). However, different odds were found for the association of milk Se with pathogen-specific incidence of IMI. The incidence of Streptococcus spp. IMI in the dry period increased with increased milk Se concentration, but the odds of new Staph. aureus IMI or CNS IMI were not affected by milk Se, suggesting that the association of milk Se concentration at drying-off with the odds of new IMI in the dry period might be pathogen-specific.

The effect of milk Se on pathogen-specific odds may be due to pathogen-associated differences in PMNL influx to the udder. Selenium-supplemented cows had a massive and rapid influx of PMNL to the udder after $E$.

Table 6. Effect of a $0.20 \mu \mathrm{mol} / \mathrm{L}$ increase in milk selenium concentration on the pathogen-specific and overall odds of having a new IMI during the dry period in 440 quarters from dairy cows from Atlantic Canadian dairy herds

\begin{tabular}{lccc}
\hline Pathogen & $\mathrm{OR}^{1}$ & $95 \% \mathrm{CI}$ & $P$-value \\
\hline Staphylococcus aureus $^{2}$ & 0.49 & $0.18,1.29$ & 0.15 \\
Streptococcus spp. $^{3}$ & 1.72 & $1.03,2.85$ & 0.04 \\
CNS $^{3}$ & 0.98 & $0.72,1.34$ & 0.91 \\
Other gram-positive pathogens $^{4}$ & 1.54 & $1.02,2.32$ & 0.04 \\
Overall $^{2}$ & 1.23 & $0.95,1.59$ & 0.11 \\
\hline
\end{tabular}

${ }^{1}$ Odds ratio.

${ }^{2}$ Final multivariable model including milk Se, province, and parity.

${ }^{3}$ Final multivariable model including milk Se and province.

${ }^{4}$ Final multivariable model including milk Se and housing system. 
Table 7. Unconditional effect of milk selenium concentration, province, season, housing system, grazing, parity, stage of lactation, and infection status on SCC (LnSCC, thousands/mL) in 492 milk samples from 262 dairy cows in 18 Atlantic Canadian dairy herds

\begin{tabular}{|c|c|c|c|}
\hline Variable & Coeff. $^{1}$ & $95 \% \mathrm{CI}$ & $P$-value \\
\hline Milk Se $(\mu \mathrm{mol} / \mathrm{L})$ & 0.16 & $-0.00,0.33$ & 0.05 \\
\hline Province & & & 0.90 \\
\hline Prince Edward Island & 0 & & \\
\hline New Brunswick & 0.03 & $-0.46,0.51$ & \\
\hline Nova Scotia & -0.08 & $-0.56,0.40$ & \\
\hline Season & & & 0.11 \\
\hline Fall & 0 & & \\
\hline Winter & 0.71 & $-0.14,1.56$ & \\
\hline Spring & 0.67 & $0.13,1.22$ & \\
\hline Summer & 0.55 & $0.02,1.08$ & \\
\hline Housing system & & & 0.96 \\
\hline Free-stall & 0 & & \\
\hline Tie-stall & -0.01 & $-0.41,0.39$ & \\
\hline Grazing & & & 0.98 \\
\hline No & 0 & & \\
\hline Yes & 0.00 & $-0.40,0.40$ & \\
\hline Parity & & & $<0.01$ \\
\hline 1 & 0 & & \\
\hline 2 to 3 & 0.48 & $0.11,0.85$ & \\
\hline$>3$ & -0.17 & $-0.52,0.17$ & \\
\hline Stage of lactation & & & $<0.01$ \\
\hline Fresh & 0 & & \\
\hline Drying-off & 0.82 & $0.57,1.08$ & \\
\hline Infection status & & & 0.02 \\
\hline Negative & 0 & & \\
\hline Major pathogen & 0.76 & $0.21,1.31$ & \\
\hline CNS & 0.39 & $-0.08,0.87$ & \\
\hline
\end{tabular}

${ }^{1}$ Coefficient.

coli IMI (Erskine et al., 1989). However, PMNL influx was slower and more efficient in killing Staph. aureus, suggesting some evidence of enhanced mammary resistance (Erskine et al., 1990). European studies have found that Se supplementation resulted in Se-dependent antibacterial activity in whey sufficient to inhibit the growth of Staph. aureus (Malbe et al., 2006). Nevertheless, the odds of having a Streptococcus spp. IMI at the beginning of lactation or Streptococcus spp. CM during lactation were not affected by Se supplementation (Smith et al., 1984, 1985). In our study, however, an explanation for the effect of milk Se concentration on the odds of new Streptococcus spp. IMI or IMI caused by other gram-positive pathogens in the dry period remains unclear, and might be related to specific PMNL function, which was beyond of the scope of our study.

The effect of selenium on the udder immune response is mediated through its incorporation into antioxidant selenoproteins (Sordillo et al., 2007); however, reaching a certain milk Se concentration does not guarantee effective incorporation into selenoproteins with a role against mammary pathogens, because approximately $15 \%$ of the daily Se intake is excreted in milk (Maus et al., 1980). This observation concurs with a recent trial reporting increased milk Se concentration after Se supplementation, but differences did not translate into an enhanced effect on PMNL function or into the clinical response following an intramammary challenge with lipopolysaccharides (Weiss and Hogan, 2005).

Milk Se concentration was positively associated with mean LnSCC, concurring with previous studies from Norway (Kommisrud et al., 2005) and Canada (Wichtel et al., 2004), possibly as a result of a more robust PMN response to IMI in well Se-supplemented cows. A positive association of milk Se concentration with SCC was found in Se-supplemented cows following an intramammary challenge with lipopolysaccharides (Weiss and Hogan, 2005), as PMNL migration following an IMI is improved in Se-adequate cows (Smith et al., 1997). Additionally, bovine blood neutrophils have extremely high activity of the selenoenzyme glutathione peroxidase, and blood cells contain a greater proportion $(\sim 73 \%)$ of blood Se than does plasma (Scholz and Hutchinson, 1979). Therefore, an increase of SCC in milk may also cause an increase in milk Se concentration due to PMNL influx into infected quarters.

Generally, SCC increases with advancing age and stage of lactation (Barkema et al., 1999), with stage of lactation explaining more variation in SCC than does parity. In our study, older cows had numerically more IMI caused by Staph. aureus, streptococci, and grampositive pathogens, which cause a greater increase in SCC compared with changes observed in CNS IMI or Corynebacterium spp. IMI (Schukken et al., 2003). The low SCC observed shortly after calving was, perhaps, the consequence of a decline in the prevalence of infection (Dohoo, 1993) or a physiological effect in culturenegative quarters (Barkema et al., 1999).

In 2003, the approval of organic Se for dairy cattle greatly expanded the options for Se supplementation, making Se supplementation a more complicated matter because differences in the bioavailability and the effect of Se sources on measures of herd productivity and udder health became more variable. Therefore, producers who have herds with typically higher SCC might intentionally supplement Se at a higher rate or may use more organic Se, resulting in a higher concentration in milk (Ceballos et al., 2009) associated with higher SCC. Nevertheless, more supplemental Se does not mean greater incorporation into the functional selenoproteins that have a role in the immune response of the udder. Evidence from recent studies does not point to an obvious effect of supplementing organic sources compared with inorganic sources on udder health (Malbe et al., 1995; Weiss and Hogan, 2005). Selenium supplementation may elicit a favorable response, but super-supplementation of Se-adequate diets will not produce additional benefits to animal performance (Silvestre et al., 2007). Higher Se intakes may have evolved over time because producers and advisers have become 
Table 8. Multivariable linear regression model of the association between milk selenium concentration, season, parity, stage of lactation, and infection status, and SCC (LnSCC, thousands/mL) in milk of 313 milk samples from 262 dairy cows in 18 Atlantic Canadian dairy herds

\begin{tabular}{|c|c|c|c|c|c|c|}
\hline \multirow[b]{2}{*}{ Variable } & \multicolumn{3}{|c|}{ Not including infection status } & \multicolumn{3}{|c|}{ Including infection status } \\
\hline & Coeff. ${ }^{1}$ & $95 \% \mathrm{CI}$ & $P$-value & Coeff. $^{1}$ & $95 \% \mathrm{CI}$ & $P$-value \\
\hline Intercept & 1.91 & $1.21,2.61$ & $<0.01$ & 1.11 & & 0.02 \\
\hline Milk Se $(\mu \mathrm{mol} / \mathrm{L})$ & 1.20 & $0.46,1.94$ & $<0.01$ & 1.33 & $0.42,2.23$ & $<0.01$ \\
\hline Season & & & 0.02 & & & 0.01 \\
\hline Fall & 0 & & & 0 & & \\
\hline Winter & -0.06 & $-0.85,0.72$ & & 0.24 & $-0.80,1.28$ & \\
\hline Spring & -0.13 & $-0.65,0.40$ & & 0.02 & $-0.56,0.59$ & \\
\hline Summer & 0.35 & $-0.15,0.85$ & & 0.58 & $0.05,1.11$ & \\
\hline Parity & & & $<0.01$ & & & $<0.01$ \\
\hline 1 & 0 & & & 0 & & \\
\hline 2 to 3 & 0.58 & $0.22,0.95$ & & 0.52 & $0.03,1.01$ & \\
\hline$>3$ & 1.33 & $0.94,1.73$ & & 1.33 & $0.81,1.86$ & \\
\hline Stage of lactation & & & $<0.01$ & & & $<0.01$ \\
\hline Fresh & 0 & & & 0 & & \\
\hline Drying-off & 1.38 & $1.06,1.71$ & & 1.55 & $1.16,1.94$ & \\
\hline Infection status & & & & & & $<0.01$ \\
\hline Negative & & & & 0 & & \\
\hline Major pathogen & & & & 0.86 & $0.37,1.36$ & \\
\hline CNS & & & & 0.65 & $0.22,1.08$ & \\
\hline
\end{tabular}

${ }^{1}$ Coefficient.

more aware of the importance of maintaining adequate Se status. Thus, we were working with a dairy population in which the ranges of milk Se concentration, the prevalence of IMI, and the SCC in milk were much more favorable than in the experimental herds $25 \mathrm{yr}$ ago when a negative relationship between Se status and udder health was first established.

\section{CONCLUSIONS}

Seasonal variations in milk Se concentration indicated that mean milk Se was marginal in $14 \%$ of the cows in the grazing season, which is most likely the consequence of insufficient Se intake due to low Se concentrations in pastures of Atlantic Canada. Although milk Se indicated adequate Se status, overall odds of new IMI in the dry period was not associated with milk Se concentration. However, milk Se was positively associated with higher odds of new Streptococcus spp. IMI and IMI caused by other gram-positive pathogens in the dry period. Milk Se concentration was also positively associated with LnSCC, possibly because of a more robust PMNL response to IMI in well-supplemented cows. Selenium status was much higher and ranges of IMI prevalence and SCC were lower in the population of our study than in the experimental herds in which a beneficial role of Se status and udder health was first noted. Under the current management conditions, and ranges of milk Se levels found, Se status did not appear to be a principal determinant of the incidence of IMI in the dry period and SCC changes shortly after calving; thus, management practices and environmental factors other than Se status determined the udder health.

\section{ACKNOWLEDGMENTS}

The Canadian Bovine Mastitis Research Network (CBMRN, University of Montreal, Saint-Hyacinthe, QC, Canada) and the Atlantic Veterinary College Research Fund (Charlottetown, PE, Canada) funded this research. The authors thank Javier Sanchez, Kristen Reyher, Raphaël Vanderstichel, Natasha Robinson, Orysia Dawydiak, and Doris Poole from the University of Prince Edward Island, and Simon Dufour from the University of Montreal for their assistance and technical help. We also thank all the technicians who collected the samples.

\section{REFERENCES}

Ali, A. K. A., and G. E. Shook. 1980. An optimum transformation for somatic cell concentration in milk. J. Dairy Sci. 63:487-490.

Barkema, H. W., H. A. Deluyker, Y. H. Schukken, and T. J. Lam. 1999. Quarter-milk somatic cell count at calving and at the first six milkings after calving. Prev. Vet. Med. 38:1-9.

Campbell, J. R., G. K. Jim, C. W. Booker, and P. T. Guichon. 1995. A survey of the selenium status of beef cows in Alberta. Can. Vet. J. 36:698-702.

Ceballos, A., J. Sanchez, H. Stryhn, J. B. Montgomery, H. W. Barkema, and J. J. Wichtel. 2009. Meta-analysis of the effect of oral selenium supplementation on milk selenium concentration in cattle. J. Dairy Sci. 92:324-342.

Dohoo, I. R. 1993. An evaluation of the validity of individual cow somatic cell counts from cows in early lactation. Prev. Vet. Med. $16: 103-110$.

Dohoo, I. R., W. Martin, and H. Stryhn. 2009. Veterinary Epidemiologic Research. 2nd ed. VER Inc., Charlottetown, Prince Edward Island, Canada. 
Erskine, R. J., R. J. Eberhart, P. J. Grasso, and R. W. Scholz. 1989. Induction of Escherichia coli mastitis in cows fed selenium-deficient or selenium-supplemented diets. Am. J. Vet. Res. 50:2093-2100.

Erskine, R. J., R. J. Eberhart, and R. W. Scholz. 1990. Experimentally induced Staphylococcus aureus mastitis in selenium-deficient and selenium-supplemented dairy cows. Am. J. Vet. Res. 51:11071111.

Fenimore, R. L., D. S. Adams, and R. Puls. 1983. Selenium levels of beef cattle in southeastern British Columbia relative to supplementation and type of pasture. Can. Vet. J. 24:41-45.

Fisher, L. J., C. Hoogendoorn, and J. Montemurro. 1980. The effect of added dietary selenium on the selenium content of milk, urine and feces. Can. J. Anim. Sci. 60:79-86.

Halasa, T., K. Huijps, O. Osteras, and H. Hogeveen. 2007. Economic effects of bovine mastitis and mastitis management: A review. Vet. Q. 29:18-31.

Kleinbaum, D. G., and M. Klein. 2002. Logistic regression. A selflearning text. 2nd ed. Springer-Verlag, New York, NY.

Kommisrud, E., O. Osteras, and T. Vatn. 2005. Blood selenium associated with health and fertility in Norwegian dairy herds. Acta Vet. Scand. 46:229-240.

Malbe, M., M. Attila, and F. Atroshi. 2006. Possible involvement of selenium in Staphylococcus aureus inhibition in cow's whey. J. Anim. Physiol. Anim. Nutr. (Berl.) 90:159-164.

Malbe, M., M. Klaassen, W. Fang, V. Myllys, M. Vikerpuur, K. Nyholm, S. Sankari, K. Suoranta, and M. Sandholm. 1995. Comparisons of selenite and selenium yeast feed supplements on Seincorporation, mastitis and leukocyte function in Se-deficient dairy cows. Zentralbl. Veterinarmed. A 42:111-121.

Maus, R. W., F. A. Martz, R. L. Belyea, and M. F. Weiss. 1980. Relationship of dietary selenium to selenium in plasma and milk from dairy cows. J. Dairy Sci. 63:532-537.

NRC. 2001. Nutrient Requirements of Dairy Cattle. 7th ed. National Academy Press, Washington, DC.

Olde Riekerink, R. G. M., H. W. Barkema, D. F. Kelton, and D. T. Scholl. 2008. Incidence rate of clinical mastitis on Canadian dairy farms. J. Dairy Sci. 91:1366-1377.

Olde Riekerink, R. G. M., H. W. Barkema, S. Veenstra, D. E. Poole, R. T. Dingwell, and G. P. Keefe. 2006. Prevalence of contagious mastitis pathogens in bulk tank milk in Prince Edward Island. Can. Vet. J. 47:567-572.

Oster, O., and W. Prellwitz. 1982. A methodological comparison of hydride and carbon furnace atomic absorption spectroscopy for the determination of selenium in serum. Clin. Chim. Acta 124:277291.

Reyher, K. K., S. Dufour, H. W. Barkema, L. Des Côteaux, T. J. DeVries, I. R. Dohoo, J.-P. Roy, and D. T. Scholl. 2010. The Na- tional Cohort of Dairy Farms - A data collection platform for mastitis research in Canada. J. Dairy Sci. doi:10.3168/jds.2010-3180

Sampimon, O., H. W. Barkema, I. Berends, J. Sol, and T. Lam. 2009. Prevalence of intramammary infection in Dutch dairy herds. J. Dairy Res. 76:129-136.

Scholz, R. W., and L. J. Hutchinson. 1979. Distribution of glutathione peroxidase activity and selenium in the blood of dairy cows. Am. J. Vet. Res. 40:245-249.

Schukken, Y. H., D. J. Wilson, F. Welcome, L. Garrison-Tikofsky, and R. N. Gonzalez. 2003. Monitoring udder health and milk quality using somatic cell counts. Vet. Res. 34:579-596.

Silvestre, F. T., H. M. Rutigliano, W. W. Thatcher, J. E.-P. Santos, and C. R. Staples. 2007. Effect of selenium source on production, reproduction, and immunity of lactating dairy cows. Page 55-67 in Proc. Fl. Rumin. Nutr. Symp., Gainesville, FL.

Smith, K. L., J. Harrison, D. Hancock, D. Todhunter, and H. Conrad. 1984. Effect of vitamin $\mathrm{E}$ and selenium supplementation on incidence of clinical mastitis and duration of clinical symptoms. J. Dairy Sci. 67:1293-1300.

Smith, K. L., J. Hogan, and W. Weiss. 1997. Dietary vitamin E and selenium affect mastitis and milk quality. J. Anim. Sci. 75:16591665 .

Smith, K. L., H. R. Conrad, B. A. Amiet, and D. A. Todhunter. 1985. Incidence of environmental mastitis as influenced by dietary vitamin E and selenium. Kieler Milchwiss. Forsch. 37:482-486.

Sordillo, L. M., N. O'Boyle, J. C. Gandy, C. M. Corl, and E. Hamilton. 2007. Shifts in thioredoxin reductase activity and oxidant status in mononuclear cells obtained from transition dairy cattle. J. Dairy Sci. 90:1186-1192.

Weiss, W. P., and J. S. Hogan. 2005. Effect of selenium source on selenium status, neutrophil function, and response to intramammary endotoxin challenge of dairy cows. J. Dairy Sci. 88:4366-4374.

Weiss, W. P., J. S. Hogan, K. L. Smith, and K. H. Hoblet. 1990. Relationships among selenium, vitamin E, and mammary gland health in commercial dairy herds. J. Dairy Sci. 73:381-390.

Wichtel, J. J. 1998. A review of selenium deficiency in grazing ruminants. Part 2: Towards a more rational approach to diagnosis and prevention. N. Z. Vet. J. 46:54-58.

Wichtel, J. J., G. P. Keefe, J. A. Van Leeuwen, E. Spangler, M. A. McNiven, and T. H. Ogilvie. 2004. The selenium status of dairy herds in Prince Edward Island. Can. Vet. J. 45:124-132.

Winter, K. A., and U. C. Gupta. 1979. Selenium content of forages grown in Nova Scotia, New Brunswick, and Newfoundland. Can. J. Anim. Sci. 59:107-111. 